\title{
LOGIKA ELITE DESA DALAM PRAKTIK PEMBANGUNAN DESA WISATA PUJON KIDUL
}

\author{
Luxy Pujo Sakti \\ Universitas Muhammadiyah Malang, luxypujo87@gmail.com
}

\begin{abstract}
ABSTRAK
Pariwisata merupakan industri terbesar dan terkuat dalam pembiayaan ekonomi global pada saat ini. Pariwisata juga menjadi penyumbang devisa terbesar di Indonesia serta memberikan dampak yang baik dalam pembangunan pariwisata desa. Elite desa berperan penting dalam mensosialisasikan ide terhadap masyarakat. Peran penting bagi elite desa dalam melakukan pemberdayaan kepada masyarakat lokal dibutuhkan realisasi guna pengembangan desa. Logika dari desa Pujon Kidul, terhadap elite desa yang telah berhasil melakukan pembangunan wisata dengan produk lokal desa dengan melakukan pemberdayaan kepada masyarakat lokal perlu dikaji secara berlanjut. Penelitian ini bertujuan untuk mengetahui Logika Elite Desa Dalam Praktik Pembangunan Desa Wisata Pujon Kidul. penelitian ini menggunakan pendekatan kualitatif dan dengan jenis penelitian deskriptif, melalui observasi lapangan, wawancara dan dokumentasi terhadap informan. Teori yang digunakan dalam penelitian ini yaitu teori dari Pierre Bourdieu mengenai praktik habitus. Tahun 2015 elite desa Pujon Kidul berhasil melakukan pembangunan kafe sawah, kampung wisata Tulungrejo, dan melakukan pengembangan di bidang wisata edukasi, hingga kini berhasil membangun Desa Wisata Pujon Kidul.
\end{abstract}

Kata Kunci : Elite, Pembangunan Desa Wisata, dan Pemberdayaan Masyarakat.

\begin{abstract}
Tourism is the largest and strongest industry in financing the global economy at this time. Tourism is also the largest contributor to foreign exchange in Indonesia and has a good impact on rural tourism development. Village elites play an important role in disseminating ideas to the community. The important role for village elites in empowering local communities requires realization for village development. The logic from Pujon Kidul village, towards village elites who have succeeded in developing tourism with village local products by empowering local communities needs to be studied continuously. This study aims to determine the Logic of Village Elite in Pujon Kidul Tourism Village Development Practices. This research uses a qualitative approach and descriptive research type, through field observations, interviews and documentation of informants. The theory used in this research is Pierre Bourdieu's theory of the practice of habitus. In 2015, the elite of Pujon Kidul village succeeded in building a rice field cafe, a tourist village in Tulungrejo, and developing in the field of educational tourism, until now they have succeeded in building the Pujon Kidul Tourism Village.
\end{abstract}

Keywords: Elite, Tourism Village Development, and Community Empowerment.

\section{PENDAHULUAN}

Pariwisata merupakan industri terbesar dalam pembiayaan ekonomi global pada saat ini. Pariwisata akan menjadi pendorong utama kemajuan perekonomian dunia pada abad ke-21 ini dan menjadi salah satu industri yang mendunia. Pariwisata merupakan salah

ISSN: 2355-6587, e-ISSN: 2528-2220

http://ejournal.bsi.ac.id/ejurnal/index.php/jp 
satu sumber penghasil devisa negara yang sangat penting dan mampu memberikan sumbangan yang cukup berarti bagi pembangunan infrastruktur maupun sosial. Produk wisata konvensional mulai banyak ditinggalkan dan wisatawan beralih kepada produk wisata yang lebih menghargai sumber daya alam. (Adawiyah dkk, 2017) Indonesia sebagai negara kepulauan terbesar di dunia yang saat ini terdiri dari 17.508 pulau atau yang sudah disebut nusantara atau negara maritim sejak zaman dahulu (Soebagyo, 2012).

Pariwisata mempunyai peran yang besar dalam memajukan serta menambah dan juga menghasilkan devisa di suatu negara. Pariwisata juga sebagai pendongkrak ekonomi negara yang mempunyai peran strategis, seperti transportasi, jasa dan juga hiburan-hiburan (Sartika dkk, 2014). Kabupaten Malang merupakan satu dari beberapa kabupaten di Jawa Timur yang memiliki basis pariwisata dangan ditunjang oleh sumber daya alam seperti pertanian, perkebunan, peternakan, dan perikanan. Kabupaten Malang juga merupakan kabupaten yang mempunyai daya tarik wisata yang beraneka ragam dan tersebar disetiap kecamatan. Daya tarik tersebut meliputi wisata alam berupa pegunungan, pantai, coban serta wisata buatan ataupun bangunan sejarah (Sukmaratri, 2018)

Desa Pujon Kidul memiliki potensi yang besar dalam melakukan pembangunan pada bidang industri pariwisata. Potensi yang dapat di tunjukan serta dikembangkan di desa Pujon Kidul diantaranya sektor pariwisata pertanian, perternakan, perkebunan serta edukasi. Pemerintah desa Pujon Kidul juga menggunakan Alokasi Dana Desa atau ADD guna melakukan pemerataan kesejahteraan untuk masyarakat Pujon Kidul dengan membangun obyek wisata Kafe Sawah, kampung budaya, dan edukasi. Pemerintah dengan memanfaatkan Alokasi Dana Desa yang turun dari pemerintah pusat guna melakukan pembangunan-pembangunan sarana dan prasarana, dan juga pembangunan pada pariwisata yang terus dikembangkan hingga saat ini.
Pengembangan Desa Wisata hingga saat ini diambilkan dari DD, dari pendapatan wisata setiap tahunnya. Pada 2018, pendapatan asli desa (PADes) dari wisata Kafe Sawah Rp 1,3 miliar, sedangkan pendapatan asli desa dari Kafe Sawah pada tahun 2019 mencapai Rp 1,5 miliar. Pada pemerintahan saat ini desa Pujon Kidul berhasil mengatasi kemiskinan, pengangguran, dan yang sangat penting yaitu pemerintah berhasil membawa masyarakatnya sedikit demi sedikit mencapai kata sejahtera (Sie.pujonkidul, 2020). Keadaan ekonomi sangatlah erat kaitannya dengan sumber mata pencaharian masyarakat serta sebagai jantung kehidupan bagi manusia. Setiap orang senantiasa berusaha mendapatkan pekerjaan sesuai dengan bidang dan keseharian masing-masing. Dari jumlah penduduk sebanyak 4.388 jiwa, dengan jumlah angkatan kerja 1.875 jiwa, kegiatan ekonomi desa Pujon Kidul selama ini masih didominasi oleh sektor pertanian dan peternakan, mengingat wilayah desa Pujon Kidul $65 \%$ persawahan yang merupakan lahan mata pencaharian masyarakat (Sie.pujonkidul, 2020).

Desa Pujon Kidul memiliki keunikan yaitu pada proses pembangunan kafe sawah yang hanya melibatkan para pemuda atau karang taruna, pemuda yang dahulunya gemar melakukan hal-hal negatif saat ini ditarik untuk ikut serta dalam pembangunan wisata yang ada di desa Pujon Kidul. Desa Pujon Kidul yang diangkat menjadi desa wisata membuka peluang yang besar sebagai peretasan pengangguran serta kemiskinan yang ada di desa Pujon Kidul, karna para pegawai dan staf kafe sawah hanya boleh berasal dari desa Pujon Kidul. Penelitian ini bertujuan untuk mengetahui logika elite desa dalam praktik pembangunan Desa Wisata dan Dampak yang ditimbulkan dari perubahan menjadi Desa Wisata.

\section{KAJIAN LITERATUR Konsep Elite}

Perbedaan yang tidak mungkin terelakkan di antara anggota masyarakat yang satu dengan lainnya adalah titik awal bagi munculnya kelompok-kelompok 
unggulan. Anggota masyarakat yang mempunyai keunggulan tersebut pada gilirannya akan tergabung dalam suatu kelompok yang lebih dikenal dengan sebutan kelompok elit.

Keunggulan yang melekat pada dirinya akan menggiring mereka tergabung dalam kelompok elit yang mempunyai perbedaan dengan anggota masyarakat kebanyakan, yang tidak memiliki keunggulan.

Terminologi elit, sebagaimana diungkapkan oleh para pemikir yang tergolong dalam elite theorists, seperti Vilfredo Pareto, Gaetano Mosca, dan Suzanne Keller menunjuk pada kelompok atau golongan yang ada di suatu masyarakat yang memiliki keunggulan atau superioritas apabila dibandingkan dengan kelompok atau golongan lainnya (Bottomore, Tom B, 1982). Menurut mereka, elit adalah posisi dalam masyarakat yang berada di puncak struktur-struktur sosial yang terpenting, seperti dalam posisi-posisi tinggi di dalam ekonomi, pemerintahan, aparat kemiliteran, politik, agama, pengajaran dan 2 pekerjaan-pekerjaan bebas (J.W. School, 1980).

\section{Konsep Pemimpin Formal}

Dalam (Pasal 14 Ayat 1 PP Nomor 72 Tahun 2005), dan berdasarkan perundang-undangan Nomor 72 Tahun 2005, pasal 14, Kepala Desa memiliki kedudukan sebagai kepala pemerintahan desa yang membawahi sebuah desa. Kepala desa mempunyai tugas untuk menyelenggarakan urusan pemerintahan, pembangunan, dan kemasyarakatan. Maksud dari urusan pemerintahan ialah, kepala desa sebagai pengatur kehidupan masyarakat yang sesuai dengan kewenangan desa, seperti pembuat peraturan desa, pembentukan lembaga kemasyarakatan, pembentuk Badan Usaha Milik Desa, dan kerja sama antar desa.

Dalam urusan pembangunan, kepala desa mempunyai tugas untuk bisa memberdayakan masyarakat dalam penyediaan sarana prasarana fasilitas umum desa, seperti jalan desa, sarana ibadah, jembatan, aliran irigasi, dan pasar desa.

\section{Konsep Pembangunan Desa Wisata}

$$
\text { Berdasarkan Undang-Undang }
$$

Nomor 32 Tahun 2004 tentang Pemerintah Daerah dan Undang-Undang Nomor 25 tahun 2004 tentang Sistem Perencanaan Pembangunan Nasional, bahwa perencanaan daerah itu harus ditempuh secara partisipatif dan berasal dari bawah (bottom up planning), yaitu bermula dari atas desa. Perencanaan pembangunan sekarang tampak lebih disentralistik dan partisipatif, yang memungkinkan pemerintah daerah menghasilkan perencanaan daerah yang sesuai dengan konteks lokal serta proses perencanaan daerah berlangsung secara partisipatif dan berangkat dari desa.

\section{Konsep Desa Wisata}

Menurut Priasukmana \& Mulyadin (2001), Desa Wisata merupakan suatu kawasan pedesaan yang menawarkan keseluruhan suasana yang mencerminkan keaslian pedesaaan baik dari kehidupan sosial ekonomi, sosial budaya, adat istiadat, keseharian, memiliki arsitektur bangunan dan struktur tata ruang desa yang khas, atau kegiatan perekonomian yang unik dan menarik serta mempunyai potensi untuk dikembangkanya berbagai komponen kepariwisataan, misalnya atraksi, akomodasi, makanan-minuman, cindera-mata, dan kebutuhan wisata lainnya.

Pengembangan konsep desa wisata dinilai sangat effektif dalam rangka mengenalkan serta memberi peluang sebesar-besarnya kepada masyarakat pedesaan untuk memahami esensi dunia pariwisata serta menikmati hasil dari kepariwisataan tersebut. Bagi daerah daerah yang memiliki karakteristik dan keunikan terutama di keseharian masyarakat desa maka pengembangan konsep ini sangat direkomendasikan. Ada tiga keuntungan yang utama dalam pengaplikasian konsep ini pada suatu daerah yaitu;

Pertama, dengan adanya desa wisata maka pengelola harus menggali dan mempertahankan nilai-nilai adat budaya yang telah berlangsung selama puluhan tahun di desa tersebut. Lestarinya nilainilai budaya merupakan daya tarik utama 
bagi wisatawan. Suatu desa tidak akan menarik jika tidak memiliki budaya, adat istiadat yang unik serta way of living yang eksotis. Kedua, dengan konsep ini maka secara otomatis masyarakat desa yang notabene memiliki kemampuan ekonomi yang kurang dapat berperan aktif dalam kelangsungan desa wisata. Dengan kata lain, timbul lahan - lahan pekerjaan baru serta pemberdayaan masyarakat desa akan semakin lebih intensif. Akhir dari konsep ini tentu saja agar peningkatan taraf hidup dan perekonomian masyarakat akan lebih termaksimalkan. Ketiga, masyarakat desa dituntut untuk lebih bersahabat dengan alam sekitar. Lingkungan yang asri, pohon-pohon yang rindang serta terawat adalah salah satu komponen daya tarik desa wisata (Wiendu, 1993).

Habitus dalam penjelasannya tentang ilmu sosial, Bourdieu menaruh perhatiannya pada apa yang dilakukan individu dalam kehidupan sehari-hari mereka. Bourdieu mengatakan bahwa kehidupan sosial tidak dapat dipahami semata-mata sebagai agregat prilaku individu. Secara literer, habitus adalah suatu kata bahasa latin yang mengacu pada kondidi, penampakan atau situasi yang tipikal atau bitual, khususnya pada tubuh (Jenkins, 2016).

Habitus juga mendasari ranah yang merupakan jaringan antar posisi objektif dalam suatu tatanan sosial dengan hadir yang secara terpisah dari kesadaran individual. Ranah bukan merupakan ikatan inter subjektif antar individu, tetapi hal ini semacam hubungan yang terstruktur dan teratur dan tanpa disadari memberi pengaturan pada posisi-posisi individu serta kelompok dalam tatanan masyarakat yang terbentuk secara spontan atau secara langsung. Habitus memberi kemungkinan kepada manusia yang hidup dalam keseharian mereka sendiri secara spontan dan mampu melakukan hubungan dengan pihak-pihak diluar dirinya. Proses interaksi dengan pihak luar itu yang terjadi, terbentuklah ranah, dan juga jaringan relasi-posisi-posisi objektif.

Ranah merupakan sebuah metafora yang digunakan Bourdieu untuk menggambarkan kondisi masyarakat yang secara terstruktur dan dinamis dengan adanya daya-daya yang dikandungnya. Ranah juga berperan dengan mengisi ruang sosial. Istilah ruang sosial mengacu terhadap keseluruhan konsepsi dunia sosial. Konsep ini menganalogikan realisasi sosial sebagai sebuah ruang dengan pemahaman menggunakan pendekatan topologi. Ruang social dalam hal ini dapat dikonsepsikan yang terdiri dari beragam ranah dengan memiliki beberapa jumlah hubungan terhadap satu dengan yang lainnya, serta sejumlah titik kontak. Ruang sosial individu kemudian dikaitkan melalui waktu (trajektori kehidupan) dengan beberapa rangkaian ranah sebagai tempat orang-orang berebut berbagai bentuk modal. Ruang sosial ini, individu dengan habitus-nya melakukan hubungan dengan individu lain serta berbagai realitas sosial dengan menghasilkan tindakan-tindakan yang sesuai dengan ranah dan modal yang dimilikinya (Takwin, 1990).

Makna arena adalah suatu sistem posisi sosial yang terstruktur yang dikuasai oleh individu atau institusi suatu inti yang mendefinisikan situasi yang mereka anut. Ini juga merupakan sistem kekuatan yang ada diantara posisi tersebut, suatu arena yang distrukturkan secara internal dalam konteks relasi kekuasaan. Posisinya ada dalam suatu relasi dengan dominasi, suboedinasi satu sama lain karna akses yang dapat mereka raih atas benda atau sumber modal yang dipertaruhkan diarena. Benda-benda ini secara prinsipil dapat dibedakan menjadi empat kategori; modal ekonomi, modal kultural, modal sosial, modal simbolis (Richard Jenkins, 2016, 125).

Ranah dikitari oleh relasi kekuasaan objektif yang memiliki basis meteril. Jenisjenis modal yang diperkenalkan dalam ranah-ranah tertentu dan yang digabungkan kedalam habitus sebagian dari hasil materil (Bagus Takwin 1990:16-17). Modal yang dimiliki desa wisata Pujon Kidul sangat beragam diantaranya ada sosial yang baik antar masyarakatnya, walaupun saat ini desa Pujon kidul menjadi desa wisata tetapi semangat gotong royong mereka tidak 
pernah surut, justru membuat masyarakat Pujon Kidul lebih bersemangat dan rukun, kebudayaan yang ada didesa Pujon Kidul juga tidak mengalami pergeseran justru saat ini kebudayaan yang ada di Pujon Kidul menjadi suguhan bagi para wisatawan lokal maupun internasional, simbol dari desa Pujon Kidul pun tidak luntur salah satunya dalah sebagai pemasok susu sapi no 1 di Jawa Timur selain susu Pujon Kidul juga dikenal sebagai daerah agrowisatanya, pada sektor ekonominya pemerintah terus memperluas area gerak mayarakat untuk mengembangkan potensi yang ada baik dari perkebunan, pertanian dan lain-lain.

Praktik merupakan suatu produk dari relasi antara habitus sebagai produk sejarah dan ranah yang juga merupakan produk sejarah. Pada saat bersamaan, habitus dan ranah juga merupakan produk dari medan daya-daya yang ada di masyarakat. Dalam suatu ranah ada pertaruhan, kekuatan-kekuatan serta orang yang memiliki banyak modal dan orang yang tidak memiliki modal. Modal merupakan sebuah konsentrasi kekuatan, suatu kekuatan spesifik yang beroperasi didalam ranah. Setiap ranah menuntut individu untuk memiliki modal-modal khusus agar dapat hidup secara baik dan bertahan didalamnya. Mereka yang memiliki modal dan habitus yang sama dengan kebanyakan individu akan lebih mampu melakukan tindakan mempertahankan atau mengubah struktur dibandingkan dengan mereka yang tidak memiliki modal.

Bourdieu dalam sebuah praktiknya akan menghasilkan sebuah prodak dari relasi antara habitus, modal, dan ranah hasil dari ketikaganya adalah sebuah keberhasilan dalam sebuah pembangunan pariwisata, membuat masyarakat semakin mandiri dari pemberdayaan yang berhasil dari usaha para elite desa, terjalinnya sebuah hubungan yang semakin erat antara masyarakat dengan para stkeholder elite desa, berkembangnya wisata agro serta merentas masalah penggangguran dan kemiskinan di desa Pujon Kidul. Secara ringkas Bourdieu menyatakan rumus generatif yang menerangkan praktik sosial dengan persamaan: (Habitus x Modal) + Ranah $=$ Praktik (Bourdieu, 1984).

\section{METODE PENELITIAN}

Penelitian yang telah dilakukan oleh penulis merukapakan bentuk penelitian deskriptif kualitatif dengan focus penelitian pada Logika Elite desa dalam Praktik Pembangunan Desa Wisata Pujon Kidul (Moelong, 2019). Elite desa yang dimaksud ialah para pemangku kekuasaan desa Pujon Kidul seperti kepala desa, perangkat desa, direktur bumdes, dan direktur kafe sawah. Lokasi penelitian penulis terletak didesa Pujon kidul, kecamatan Pujon Kabupaten Malang.

Metode pengumpulan data yang digunakan penulis ialah menggunakan wawancara, observasi dan dokumentasi. Dalam teknik penentuan subjek penulis menggunakan purposive sampling yaitu dengan pertimbangan tertentu. Pada teknik analisis data kualitatif penulis menggunakan, reduksi data, penyajian data, dan penarikan kesimpulan Miles dan Huberman (Miles dkk, 2014).

\section{PEMBAHASAN \\ Logika Elite Desa Dalam Praktik Pembangunan Desa Wisata}

Pemerintah desa Pujon Kidul yang dipimpin oleh Udi Hartoko, kini menjadi salah satu desa maju dan mandiri di Indonesia. Berkat dari sentuhan sang aksesos ini, desa Pujon Kidul berhasil menjadi desa wisata. Pencapaian ini dimulai ketika Udi Hartoko menjabat kepala desa pada tahun 2011 hingga saat ini. Udi Hartoko tidak hanya menyelenggarakan urusan pemerintahan, pembangunan, dan kemasyarakat saja, tetapi ia juga sebagai aktor dilapangan dan penginspirasi warga Pujon Kidul. Pembangunan desa wisata Pujon Kidul membutuhkan waktu yang cukup panjang hingga mencapai kesusksesan pada saat ini, elite desa Pujon Kidul banyak mengalami kegagalan-kegagalan dalam proses pembangunan maupun pengembangan wisata Pujon Kidul.

Tahapan atau proses lahirnya logika elite hingga menjadi sebuah ide ataupun gagasan yang hakiki sebagai berikut: 


\section{Tahapan pertama}

Pada tahapan pertama ide yang dimiliki Udi Hartoko mengenai pandangan desa wisata yang akan diterapkan di Desa Pujon Kidul tersebut berawal dari kegiatan beliau mengolah lahan atau tanah di sela kesibukannya sebagai kepala desa, tanah yang saat ini dibangun kafe sawah merupakan tahah hibah atau bengkok desa yang menjadi jatah dari kepala desa tetapi justru ia gunakan dan ia manfaatkan sebagai pembangkit ekonomi masyarakat desa Pujon Kidul. Letak dari tanah hibah tersebut memiliki pemandangan yang luar biasa dalam menyajikan potensi alam yang dimiliki desa tersebut, hamparan persawahan yang luas dan hijau serta dikelilingi oleh beberapa gunung, kemudian di sore hari juga dapat menikmati keindahan alam ketika matahari mulai terbenam, seperti kutipan wawancara sebagai berikut: "ketika saya sudah menjabat sebagai kepala desa, dan seperti yang sudah ada dalam visi misi saya menginginkan desa Pujon Kidul ini bisa lebih maju dan ramai. Yaitu dengan cara menjadikan desa Pujon Kidul menjadi desa wisata, pada waktu itu saya mengundang para anggota karang taruna dan perangkat desa untuk merapatkan hal ini”

\section{Tahapan Kedua}

Logika atau ide sebenarnya sudah ada dibenak Udi Hartoko ketika ia masih menjadi warga masyarakat biasa. Ia sempat menyayangkan kenapa desa yang indah seperti Pujon Kidul tidak dapat dimanfaatkan menjadi peluang bisnis yang mampu memberikan dampak ekonomi, sosial pada masyarakatnya. Ketika tahun 2011 ia mempunyai peluang untuk maju mencalonkan sebagai kepala desa dengan membawa visi dan misi mengangkat wisata, dan menjadikan desa Pujon Kidul menjadi desa Wisata. Seperti ini kutipan wawancara bersama Kepala desa Udi Hartoko: "Pada waktu itu semua orang menertawakan saya, ketika saya bilang desa ini akan saya jadikan desa wisata, tetapi dengan semangat yang kuat saya tetap melakukan dan berusaha memberikan pengertian kepada masyarakat. Pada waktu itu saya bersama dengan pemuda desa melakukan map mapping selama 21 tempat untuk mensosialisaikan tentang desa wisata"

Proses dari map mapping yang dilakukan elite desa memakan waktu tiga hari untuk menjajaki 21 tempat perkumpulan masyarakat. Dalam melaksanakan map mapping elite dibantu oleh perangkat desa dan juga anggota karang taruna guna menjelaskan visi dan misi untuk menjadikan desa Pujon Kidul menjadi desa wisata. Namun pada pelaksanaan map mapping tidak sedikit mengalami kendala, namun hampir pada semua titik yang dituju selalu terbentur oleh kendala dari masyarakat yang dinilai program wisata ini tidak cocok dikembangkan didesa pujon kidul, seperti wawancara dengan Suhartono sebagai berikut: "masyarakat desa Pujon Kidul hanya memahami bahwasanya wisata adalah datang ke kota, kepantai, kegunung dan dan ke Jatim Park saja dan tidak memahami apa itu desa wisata"

Elite desa Pujon kidul terus melakukan pemahaman kepada masyarakat desa Pujon Kidul dengan berbagai cara yang bisa dilakukan dan dinilai dapat membawa dampak yang baik kepada masyarkat. Dengan melakukan map mapping ke seluruh desa Pujon Kidul untuk memberikan pencerahan kepada warga mengenai desa Wisata. Adapun tujuan dari ide Udi Hartoko dengan adanya desa wisata seperti, menyelamatkan masyarakat dari kemiskinan, menyelamatkan masyarakat dari pengangguran, menyelamatkan masyarakat yang putus sekolah, dan meningkatkan taraf hidup masyarakat desa Pujon Kidul.

\section{Tahapan Ketiga}

Pembangunan sumber daya manusia sangat diperhatikan dalam pembangunan desa wisata Pujon Kidul, karena dengan adanya SDM yang baik dan unggul maka akan menghasilkan ide atau kreatifitas yang baik juga. Elite hingga saat ini masih tetap melakukan binaan-binaan kepada masyarakat desa Pujon Kidul, namun tantangannya berbeda dengan pada tahap awal pembangunan yaitu penggalian potensi dan kreatifitas, sedangkan saat ini 
ialah binaan mengenai dampak negatif seperti mengikuti tren gaya berbusana, apabila hal ini masyarakat tidak dapat menyaring budaya baru tersebut yang dibawa oleh wisatawan ke Desa Pujon Kidul.

\section{Tahapan Keempat}

Elite desa

dalam proses pembangunan desa wisata menjadi aktor nomor satu di desa Pujon Kidul, karna semua keputusan berada ditangan elite desa. Pembangunan tidak semata-mata hanya berfokus pada pembangunan infrastruktur, tetapi meliputi pembangunan kemasyarakatan atau SDM masyarakat desa Pujon Kidul. Elite pada saat pembangunan desa wisata sudah sepenuhnya dipercayai oleh masyarakat desa Pujon Kidul, dengan cara sosialisasi oleh elite desa mencoba meyakinkan masyarakat nantinya pembangunan ini akan sukses dan mampu menyerap tenaga kerja.

\section{Hasil Produk Wisata Desa Pujon Kidul}

Desa Pujonkidul dikenal sebagai desa edukasi pertanian dan peternakan serta memiliki daya tarik wisata berupa perpaduan antara panorama pegunungan, sawah dan kuliner khas desa yang dikenal sebagai "Kafe Sawah". Berikut gambaran destinasi wisata yang dimiliki Desa Wisata Pujon Kidul:

\section{Wisata Edukasi Pertanian dan Peternakan}

Desa Wisata Pujon Kidul saat ini tidak hanya menggembor-gemborkan produk wisata Kafe Sawah saja, namun saat ini di 3 Dusun yang ada didesa Wisata Pujon Kidul terus digali potensi apa saja yang dapat dikelola dan dijadikan konsumsi bagi wisatawan yang berkunjung ke desa Pujon Kidul. dusun Maron Pujon kidul dikenal sebagai dusun dengan pengusaha UKM terbaik, dan pengelola peternakan dan sapi perahnya. Wisatawan yang datang kedesa Pujon Kidul pasti akan diarahkan untuk menuju dan mencicipi hasil olehan dari masyarakat dusun Maron, yaitu dengan membawa hasil UKM warga dan jug hasil olahan sapi warga desa dusun Maron.
Mayoritas masyarakat desa Pujon Kidul berpofesi sebagai petani dan peternak, ternak hewan yang dipelihara serta dikembangkan diantaranya sapi, kambing dan ayam. Selain hewan-hewan tersebut dapat membantu dalam pengolahan lahan pertanian, juga dimanfaatkan sebagai edukasi. Wisata edukasi peternakan yang ditawarkan oleh Desa Wisata Pujon Kidul yaitu pemilihan pakan yang bagus, cara merawat hewan agar tidak terserang penyakit, cara menangani penyakit pada hewan dengan memberi ramuan tradisional, dan cara pemerahan susu sapi yang tepat. Seperti kutipan dengan Ibadurohman: "Mayoritas penduduk desa Pujon Kidul saat ini adalah bertani dan berkebun, baik dilahan sendiri maupun lahan milik orang lain sebagai buruh ada disamping itu masyarakat juga banyak yang beternak sapi perah untuk mengisi kelonggaran waktu ketika pulang dari sawah"

Wisatawan yang datang kesana biasanya berupa rombongan dari sekolahsekolah, dinas pertanian, pemerintahan yang sedang melakukan studi banding, dan dari perusahaan yang berhubungan dengan pertanian yang memiliki tujuan untuk mempelajari seluk beluk pertanian serta peternakan. Hal ini dikarenakan Desa Wisata Pujon Kidul merupakan desa wisata berbasis edukasi. Selain itu, Desa Wisata Pujon Kidul juga menawarkan wisata petik sayur dan buah kepada pengunjung.

\section{Kafe Sawah}

Kafe Sawah adalah tujuan wisata yang paling dicari ketika wisatawan sedang melakukan perjalan wisata ke desa Pujon Kidul, Kafe Sawah terletak di dusun Krajan desa Pujon Kidul. dusun Krajan tidak hanya menyediakan Kafe Sawah dan destiasi wisata saja, disamping itu didusun Krajan juga menyediakan home stay yang dapat digunakan wisatawan yang ingin bermalam di desa Pujon Kidul. Seperti kutipan wawancara dengan Ibadurohman: "kafe sawah hadir untuk menjawab permasalahan yang ada dimasyarakat desa baik permasalahan kemiskinan, pengangguran maupun putus sekolah. Pemerintah menyaring masyarakat untuk

ISSN: 2355-6587, e-ISSN: 2528-2220

http://ejournal.bsi.ac.id/ejurnal/index.php/jp 
dibina dan dipekerjakan di kafe sawah dengan awal melakukan pembekalan atau training selama tiga bulan dengan gaji 800 ribu dengan 3 kali makan gratis"

Kafe sawah hadir untuk menjawab permasalahan sosial ekonomi pada masyarakat desa Pujon Kidul, masyarakat diharapkan mampu berpartisipasi dalam penyelenggaraan pemerintahan ataupun pembangunan serta pengembangan wisata yang ada di desa Pujon Kidul. Kafe Sawah Pujon Kidul hanya bermodal bengkok atau lahan hibah milik desa, pemerintah desa bersama dengan masyarakat desa Pujon kidul mulai bergerak dalam pembangunan Kafe Sawah mulai dari tahun 2016. Perpaduan antara panorama pegunungan, sawah, dan kuliner khas desa menjadikan tempat ini sebagai daya tarik wisata yang dikenal dengan Kafe Sawah. Didukung musik gamelan dan hawa sejuk menambah suasana di Kafe Sawah ini menjadi nyaman dan tenang. Para wisatawan juga dapat menikmati hidangan khas desa di tengah sawah, hingga saat ini jumlah wisatawan yang datang ke kafe mencapai 700-1000 pada hari biasa dan pada hari libur dapat mencapai 4.500 pengunjung (sie.pujomkidul, 2020).

\section{Kampung Budaya Tulungrejo}

Kampung budaya Tulungrejo adalah sebuah kampung wisata yang disediakan oleh pemerintah desa Pujon Kidul, untuk menambah destinasi wisata yang ada di desa Pujon Kidul. kampung budaya Tulungrejo terletak di dusun Tulungrejo, disini wisatawan dapat menikmati dan belajar cara membuat batik, topeng khas malangan, serta wisataan juga bisa belajar kesenian atau tari-tarian khas desa Pujon Kidul. Seperti kutipan wawancara dengan Suhartono:"Kampung budaya terletak didusun Tulungrejo desa Pujon Kidul, wisatawan mampu menikmati edukasi kesenian baik dari seni tari maupun pembuatan topeng ciri khas kabupaten Malang”

\section{Analisis Teori}

Analisis dari Logika Elite desa dalam Prektik Pembangunan Desa Wisata ditinjau dari teori Pierre Bourdieu mengenai Praktik Habitus yang berorientasi pada praktik pembangunan desa wisata, menurut Bourdieu habitus adalah struktur kognitif yang memperantai individu dalam realitas sosial. Habitus merupakan struktur subjektif yang terbentuk dari pengalaman individu berhubungan dengan individu lain dalam jaringan struktur objektif yang ada dalam ruang sosial.

Habitus dalam realitas sosial menaruh perhatiannya pada apa yang dilakukan individu dalam kehidupan sehari-hari mereka. Dalam artian habitus, merupakan hasil pemberlajaran melalui aktifitas interaksi yang dilakukan individu dalam ruang sosial, habitus bukan produk bawaan individu, tetapi merukapan hasil yang didapatkan dalam interaksi sosial, bermain dalam ruang sosial. Setiap individu mempunyai pandangan nilai habitus yang berbeda satu sama lain. Habitus dalam praktiknya melahirkan logika yang dapat diterima oleh akal (Jenkins, 2016).

Munculnya logika elite atau akal pemikiran dalam pembangunan desa wisata ini dipelopori oleh kepala desa Pujon Kidul Udi Hartoko. Seperti kutipan wawancara dengan Suhartono: "Embrio wisata sebelum 2011 sudah ada, tetapi penggeraknya juga pak Udi Hartoko pada waktu itu. Tahun 2011 sudah ada wisata alam camping ground, of rood, sumber mata air pitu, dan wisata edukasi. Edukasi pertania, peternakan itu juga yang menggagasnya juga pak Udi Hartoko dan pemuda desa yang saat ini dibentuk kelompok sadar wisata"

Udi Hartoko merupakan warga asli desa Pujon Kidul yang paham potensi desa Pujon Kidul, hingga pada suatu hari ia memberanikan diri untuk mengawali sebuah pembangunan masyarakat melalui pemanfaatan potensi alam desa menjadi wisata. Beliau juga mempunyai pemikiran akan memperbaiki kondisi desa yang dipimpinnya pada saat ini serta memanfaatkan potensi alam desa, pertanian desa, dan peternakan yang ada di desa Pujon kidul. Pemikiran tersebut muncul ketika adaya keinginan yang mengarah pada gerakan perubahan baru di desanya dengan memanfaatkan potensi 
yang dimiliki seperti potensi alamnya, yang di dalamnya melibatkan semua masyarakat dan generasi mudanya, karena Udi Hartoko menganggap bahwa peran masyarakat dalam pembangunan desa wisata sangatlah penting dan juga dapat membantu dalam tenaga fisik maupun pikiran.

Udi Hartoko dikenal sebagai kepala desa yang merakyat dan juga menjadi pemimpin yang selalu mendengarkan aspirasi atau ide dari masyarakat, disamping itu ia juga merupakan pemimpin yang tidak hanya mengayomi tetapi juga mau merangkul masyarakat dan pemuda desa Pujon Kidul. dalam hal menyalurkan ide atau aspirasi seluruh ide yang telah disampaikan difokuskan pada pemberdayaan masyarakat yang mengarah pada pembangunan wisata desa. Desa Pujon Kidul dikenal sebagai desa yang memiliki potensi alam yang dapat dimanfaatkan sebagai tempat atau destinasi wisata alam. Proses pemberdayaan masyarakat berorientasi pada pembangunan desa wisata yang khususnya Kafe Sawah Pujon Kidul, disini warga asli desa Pujon Kidul dapat bekerja hanya dengan menggunakan kartu keluarga asli Pujon Kidul dan KTP Pujon Kidul, seperti kutipan wawancara dengan Ibadurohman direktur BUMDES Sumber Sejahtera: "pada tahun 2010 warga desa Pujon Kidul rata-rata penduduk kami lulusan SMP dan pada waktu itu tingkat kriminalitas tinggi, pengangguran tinggi, putus sekolah tinggi banyak sekali warga kami yang bekerja sebagai TKI dan bekerja di kota-kota seperti Malang dan Surabaya. Pemerintah berfikir apa sampai seterusnya akan seperti ini? Lalu tidakkan. Maka dari permasalahan tersebut pemerintah melalui visi dan misinya membentuk POKDARWIS untuk menangani, mengembangkan, dan mengelola wisata yang nantinya diharapkan mampu menyerap tenaga kerja masyarakat lokal".

Meskipun pada awal proses pembangunan desa wisata Pujon Kidul masyarakat tidak memberikan respon yang baik dan mendukung program yang digagas pemerintah desa, perangkat desa, dan penggerak desa wisata Pujon Kidul.
Banyak upaya yang telah dilakukan oleh elite desa untuk mengajak masyarakat dan generasi muda pada umumnya untuk bersama-sama berproses atau berpartisipasi dalam proses pembangunan desa wisata Pujon Kidul. Namun juga masyarakat tidak banyak yang bergerak dan tersentuh, namun mereka terlebih menuntut untuk pemerintah memberikan bukti terlebih dahulu dan jika berhasil baru masyarakat ingin atau berpartisipasi dalam pembangunan serta pemberdayaan yang dilakukan oleh elite desa Pujon Kidul.

Kafe Sawah adalah bukti dari berhasilnya pembangunan desa wisata oleh elite desa Pujon Kidul, serta pemberdayaan yang dilakukan oleh elite terhadap masyarakat desa Pujon Kidul guna menurunkan angka pengangguran, kemiskinan, dan putus sekolah didesa Pujon Kidul. Pemberdayaan masyarakat tidak semata-mata hanya mempekerjakan masyarakat desa pujon Kidul di Kafe Sawah saja, tetapi eliti juga memberikan penanaman pengetahuan mengenai desa wisata serta memberikan contoh bagaimana menjalankan desa wisata dengan baik serta mandiri dan tidak bergantung pada investor, mencoba untuk membuka pemikiran masyarakat mengenai kemampuan dari generasi muda untuk memanfaatkan peluang potensi alam Pujon Kidul yang melimpah yang dapat dimanfaatkan dan dikelola dengan baik serta berujung pada kesejahtraan masyarakat desa Pujon Kidul.

Modal memiliki definisi yang sangat luas dan mencakup hal-hal material, kultural, status, dan otoritas (Takwin, 1990). Seperti halnya dalam pembangunan desa wisata Pujon Kidul, elite mempunyai role atau peran yang mampu mempengaruhi masyarakat untuk tunduk dan mengikutinya. Meskipun pada realitasnya, tidak semua elite mampu mempengaruhi masyarakat. Berbekal dengan potensi alam desa Pujon Kidul, elite berhasil memanfaatkan dan mengelolanya dengan baik seta mampu memberikan dampak positif pada masyarakat desa Pujon Kidul dengan memberikan lapangan pekerjaan, serta 
memberikan peluang usaha kepada masyarakat.

Budaya semangat gotong royong masyarakat desa Pujon Kidul tidak dapat dapat dilupakan dalam pembangunan desa wisata, walaupun pada awalnya elite membutuhkan waktu yang cukup panjang dalam proses pedekatan terhadap masyarakat Pujon Kidul. Masyarakat Pujon Kidul mempunyai semangat yang sangat kompak dalam pembangunan desa wisata Pujon Kidul, mereka juga tidak hanya menyumbangkan ide atau gagasan saja, tetapi juga tenaga fisik dan material mereka rela mengeluarkan demi kesuksesan dan keberhasilan terciptanya desa wisata.

Elite tak sekedar posisi yang mampunyai otoritas saja, namun elite juga harus mampu memberikan contoh kepada masyarakat untuk bertindak dan berprilaku baik, karna sejatinya elite desa adalah individu yang mempunyai kekuasaan dan individu yang mampu menjadi teladan bagi masyarakatnya. Elite desa Pujon Kidul kini menjadi percontohan atau teladan bagi elite-elite diluar sana, karena keberhasilannya dalam mengelola, memanfaatkan, memberikan dampak baik kepada masyarakatnya dan mengubah sikap masyarakat Pujon Kidul dari kriminalitas menjadi seorang individu yang berkualitas. Dampak dari pembangunan wisata didesa Pujon Kidul memang sudah sangat terlihat jelas, tidak hanya dilihat dari pendapatan asli desanya saja, tetapi dari segi kemajuan desa, serta menurunnya jumlah keluarga miskin, putus sekolah, dan pengangguran.

\section{PENUTUP \\ Simpulan}

Berdasarkan hasil penelitian yang telah dilakukan melalui observasi, wawancara, dan dokumetasi dapat disimpulkan bahwa embrio desa wisata Pujon Kidul dimulai sejak tahun 2011, ketika Udi Hartoko menjabat sebagai kepala desa Pujon Kidul. Pada tahun 2011 desa Pujon Kidul sudah memiliki wisata edukasi pertanian dan peternakan, tetapi wisata edukasi tersebut tidak banyak menarik wisatawan untuk berkunjung, akhirnya pada tahun 2015 pemerintah desa Pujon Kidul membuat rencana pembangunan destinasi wisata yang memanfaatkan potensi desa baik alam maupun edukasi. Pemberdayaan masyarakat mampu dikembangkan dalam Desa Pujon Kidul. Elite desa juga mampu memberi peningkatan kesejahteraan masyarakat melalui pengembangan desa wisata sebagai destinasi pariwisata.

\section{Saran}

Berdasarkan simpulan di atas maka peneliti memberikan saran bagi elite desa Pujon Kidul harus mampu menjadi teladan yang baik kepada masyarakat, dan mampu mewujudkan desa yang jauh lebih baik lagi serta membimbing para warga masyarakatnya untuk lebih aktif berpartisipasi dalam pembangunan dan pengembangan wisata desa Pujon Kidul dengan melihat potensi alam yang melimpah. Elite desa Pujon Kidul harus manjadi contoh bagi masyarakat dalam menjalankan kehidupan sosial dan memberikan bimbingan kepada seluruh warga desa Pujon Kidul, agar masyarakat juga dapat bekerja di desa sendiri dan tidak ada yang merantau keluar kota lagi, serta saran yang terakhir ialah pengelolaan sampah desa Pujon Kidul harus lebih baik lagi, baik dari pengelolaan melalui BUMDES maupun pemanfaatan sampah plastik maupun kompos.

Saran bagi penelitian selanjutnya diharapkan bisa kembali menggali informasi mengenai pembangunan atau strategi untuk kembali bangkit dalam pembangunan desa wisata pasca pandemi Covid-19 yang telah merugikan bidang ekonomi sosial pariwisata.

\section{REFERENSI}

Adawiyah W, dkk. (2014). Strategi Pengembangan Desa Wisata Berbasis Masyarakat (Community Based Rural Tourism) Di Desa Papringan. Pros Semin Nas dan Call Pap. 2017;5(November):1072-1083.

Bottomore, Tom B. (1982). Pembahasan Vilfredo Pareto dalam bukunya 
"The Mind and Society". New York: Penguin Books Ltd.

Dewi Sartika dkk. (2014). Kontribusi Sektor Pariwisata Terhadap GDP Indonesia 2004-2009. Economics Development Analysis Journal, EDAJ 3 (2) 2014.

Hermawan, Hary. (2016). Dampak Pengembangan Desa Wisata Nglanggeran Terhadap Ekonomi Masyarakat Lokal. Jurnal Pariwisata 3(2): 105-17.

Jenkins Richard. (2016). Membaca Pikiran Pierre Bourdieu. Bantul: Kreasi Wacana.

Made Heny, Chafid, Baiquni. (2013). Pengembangan Desa Wisata Berbasis Partisipasi Masyarakat Lokal di Desa Wisata Jatiluwih Tabanan, Bali. Jurnal Kawistara 3(2): 129-39.

Miles, M. B., Huberman, A. M., \& Saldana, J. (2014). Qualitative Data Analysis : A Methods Sourcebook. Thousand Oaks: SAGE Publications, Inc.

Moleong, Lexy J. (2009). Metodologi Penelitian Kualitatif . Bandung: PT. Remaja Rosdakarya.

Myrna Sukmaratri, (2018). Kajian Pola Penggerak Wisatawan di Daya Tarik Wisata Alam Kabupaten Malang. Jurnal Pariwisata Pesona, Volume 03 No 1, Juni 2018: hal. 33-45.

Nuryanti, Wiendu. (1993). Concept, Perspective and Challenges, makalah bagian dari Laporan Konferensi Internasional mengenai Pariwisata Budaya. Yogyakarta: Gadjah Mada University Press.

Priasukmana, Soetarso \& R. Muhamad Mulyadin. (2001). Pembangunan Desa Wisata : Pelaksanaan Undang-undang Otonomi Daerah. Jurnal Sosial Ekonomi. Vol. 2 No. 1 pp: 37 - 44.

Schoorl, J.W. (1980). Modernisasi. Jakarta: Gramedia.

Sie Wisata Desa Pujon Kidul. (2020). (https://www.sie.pujonkidul.desa. $\mathrm{id} /$ paketwisata.php). diakses pada 30 Juli 2020 pukul 20.00.

Soebagyo. (2012). Strategi Pengembangan Pariwisata Di Indonesia. Jurnal Liquidity, Volume.1. No. 2, Juli-Desember 2012: 153-158.

Susyanti, Winarni. (2013). Potensi Desa Melalui Pariwisata Pedesaan. Ekonomi dan Bisnis 12(1): 3336Soebagyo. 2012. Strategi Pengembangan Pariwisata Di Indonesia. Jurnal Liquidity, Volume.1. No. 2, Juli-Desember 2012: 153-158.

Takwin Bagus. (1990). Habutus x Modal + Ranah $=$ Praktik Pengantar Paling Komperhensif kepada Pemikiran Pierre Bourdieu. Yogyakarta:Jalasutra.

\section{BIODATA PENULIS}

Luxy Pujo Sakti, Lahir di Mekar Jaya, 10 Maret 1998. Meraih gelar sarjana program studi Sosiologi Universitas Muhammadiyah Malang pada tahun 2020.

ISSN: 2355-6587, e-ISSN: 2528-2220

http://ejournal.bsi.ac.id/ejurnal/index.php/jp 